\title{
A Study on Effect of Forest Education Program for Juvenile Probationers
}

\author{
Jin Jang, Yeon-Hee Lee*, and Si-Yeon Ha \\ Department of Forest Welfare, National Institute of Forest Science, Seoul 02455, South Korea
}

\begin{abstract}
This study was performed to analyze the effect of forest education on juvenile probationers'psychological and emotional changes. Changes of resilience, mood state and attitudes toward forest of 272 juvenile probationers, who attended forest education program co-managed by Korea Forest Service and Ministry of Justice in 2016, were identified by self-report survey. Survey analysis was performed using descriptive statistics, reliability analysis, exploratory factor analysis and paired t-test with IBM SPSS 21.0 program. The forest education program consisted of physical activity, emotional activity, cognitive activity, challenging activity and problem solving activity (e.g. physical exercises in the forest, forest meditation, observing forest with mirror, talking with trees, creating with natural objects, etc.). The result was as follows: First, it showed that program using forest education activities for juvenile probationers has an effect on the development of resilience. Second, it showed that program using forest education activities for juvenile probationers had an effect on the improvement of mood state. Third, it showed that program using forest education activities for juvenile probationers had an effect on the development of attitudes toward forest. It showed that program using forest education activities for juvenile probationers had an effect on the development of enjoying the forest and importance and usefulness of forest by sub-factors of attitudes toward forest. Therefore the result came out that forest education program had influence on positive change of juvenile probationers' resilience, mood state and increase of attitude towards forest. This study had a limitation to generalize the result of the study for the limited case, but forest education was expected to help the social adaptation and development of the at-risk youth who was exposed to the current risk. The next study need for various experts'cooperation to develop customized forest education programs for juvenile probationers and continuous monitoring of the effect.
\end{abstract}

Key words: adolescent probationers, attitude towards forest, forest experience, mood state, resilience

\section{I . Introduction}

These days, due to rapidly changing social environment, when the youth fail to understand their role and adapt themselves to the surroundings, they may develop lower self-esteem, emotional confusion and suspend their education or run away from home or fail to fit to school, which is a very serious situation. From this realistic perspective, the Ministry of Justice has implemented a 'probation system' since 1989 to prevent juvenile offenders and recidivism. 'Probation' is an advanced criminal policy that a criminal is not detained in a prison or youth detention center, but has a normal life in home, school,

Received on May 16, 2017. Revised on June 7, 2017.

Accepted on June 15, 2017.

*Comesponding author: shinerlee@korea.kr

This paper was conducted with the support of the National Institute of Forest Science of the Korea Forest Service for post-master's and post-doctoral researchers in 2017. or work at the same time he or she must observe the regulations prescribed by the law, be guided or supervised by a probation officer, or serve the community or comply with the order to attend a lecture in order to limit criminal nature (Crime Prevention Policy Bureau, 2016). According to the data from the justice ministry, the most frequent problematic behavior type of juvenile probationers in Korea in 2016 were theft $(6,078,37.3 \%)$ and violence $(4,719,27.5 \%)$. The proportion of re-offenders of juvenile delinquency is once - 975 (42.0\%), twice $-5,301$ (27.9\%), three times - 3,021 (15.9\%), four times $-1,584(8.3 \%)$, more than five times - 1,103 (5.8\%), which means juvenile climes have high recidivism as well. Compared with $5.6 \%$ of adult recidivism, the rate for juvenile re-offenders is $12.3 \%$, over twice more than that of adults (E-Country Index, 2017).

The youth have been mostly involved with minor delinquencies and these delinquencies have become collective behavior along with a rising delinquencies among the enrolled 
students (Kwak et al., 1991). Most of all notable is the fact that it can be more serious since the rapid increase of juvenile delinquency is not temporary but repetitive, which can ultimately grow into adult crimes (Hwang, 2010). As for these youth criminals, a combination of environmental and psychological factors related to education, family background, or relationship with their peers can influence their repetitive crimes (Noh, 2009; Lee, 2007). From this perspective, if family and society fail to function properly, it becomes highly likely to create a confusion in values and bring about side effects such as delinquent behavior (Wang, 2006). Actually, in many cases juvenile probationers who became involved in youth crimes were in vulnerable family environment and deviated from schools and accordingly they showed psychological and emotional problems. Due to low self-esteem, they are vulnerable to poor mental health such as psychological anxiety, negative attitude and a sense of alienation (Kim et al., 2015). Because when they fail to respond to problems such as conflicts with their family or peers, pressure from school or society, they can show various behavioral problems such as suicide, school violence, smoking, drinking or runaway from home (Pelkonen et al., 2003; Michael and Ben-Zur, 2007; Woo, 2009; Jang, 2010; Kim, 2012) we need to help them to effectively solve the problems they face and adapt to the environment.

According to the previous researches in Korea concerning juvenile probationers. there has been continuous studies to analyze and understand the problem factors as a part of characteristics of these youth. Hong (2000) verified that the counseling juvenile probationers dependant on personal, family and delinquency related factors is effective and Joo and Lee (2008) analyzed the statements on daily lives of delinquent youth after their second crime and categorized the developments and types of daily lives according to the repeated crimes. The study by Son and Yang (2009) suggested the tools used for correction of delinquent youth by understanding their resocialization process and developing a substance theory on the process. Koh et al. (2010) decided the characteristics of criminal's personality by measuring through PAI (Personality Assessment Inventory) on the crime types based on delinquency triggering points of the juvenile delinquents. In addition, recently there has been a study on the supports such as developing educational program for delinquency prevention. An and Park (2016b) tried to come up with measures to support juvenile delinquents after analyzing adaptation process as an influencing factor for juvenile delinquents at the facility to have willingness to return to the society after re-offence during adolescence according to personal, social and environmental factors (Song and Choi, 2016). Likewise, Studies on juvenile probationers have focused on causes of delinquency, re-offence, forecast and tried to identify root causes of crimes and make improvements. Meanwhile, programs to treat juvenile probationers differentiated from that for adults are insufficient due to difficulties in selecting external consigned institutions and shortcomings in specialized lecture programs (Cho, 2012), and the relevant studies are also insufficient.

Recently, forest education program, one of the educational programs for adolescent probations has been extensively implemented. Various studies confirmed that forest education has positive effects on depression alleviation, self-esteem improvement, emotional development, confidence boost, natural sociability, alleviation of internet addition, etc. (Kim and Lee, 2006; Shin et al., 2007; Kim, 2009; Kim, 2011; Lee, 2013). In particular, activities of experiencing forest have positive impacts on solving problems such as failure to fit to school, broken family, drug addiction and juvenile delinquency (Oh et al., 2012). Against this backdrop, the Korea Forest Service and the ministry of justice made an agreement to develop and run forest education program designed for juvenile probationers in connection of relevant professionals including forest education experts, youth specialist and probation experts and have continued to make monitoring the effects. As a part of this, Eom et al. (2016) verified positive effects of forest education program for juvenile probationers such as self-esteem and self-control improvement. In other words, they observed that participants of the forest education program were able to delay their desires, comply with regulations and enhance their life satisfaction in the long term. However, though there have been many studies to verify the effects of forest education targeting general youth, it is still insufficient to study the effects of forest education program that prevents juvenile probationers from committing crimes again and helps them to come back to society.

Therefore, this study was performed to analyze resilience, mood state and changes in their attitude towards forest as an 
emotional response of juvenile probationers before and after the forest education program and verify whether it has positive effects.

\section{Research Method}

\section{Research Subject}

The study worked on 272 juvenile probationers selected form 20 probation offices as a part of the project "2016 Korea Forest Service and Ministry of Justice's Forest Education Program for Juvenile Probationers", co-managed by Korea Forest Serve and Ministry of Justice from May to November, 2016.

\section{Forest Education Program}

The representative best practice of overseas forest education program targeting juvenile probationers is 'Wilderness Camps or Challenge Program; WCCP', a model program of Office of Juvenile Justice and Delinquency Prevention; OJJD in the US. In this program, the participants challenge their physical activities such as outdoor walking with backpack or rockclimbing. This is an opportunity for these young people to make physical, emotional and social changes through the process of 'learning through practice' (Lee, 2008).

In case of Canada, there is Coastline Challenges Program, a judiciary service education program, organized by British Columbia. In this program, juvenile probationers from age $13-18$, recommended by probation officer participate in forest education program made up of outdoor activities including camping, canoe, hiking, solo experiences and running in forest for 26 days, being disconnected from outside (National Institute of Forest Science, 2015).

In Korea, since 2014 'forest education for juvenile probationers' co-managed by Korea Forest Service and Ministry of Justice has been operated. There are various forest experience programs for these young people to foster emotion, form sound values, and have positive attitude towards forest and life through forest education such as healing forest, recreational forest and urban forest.

In this way, forest education programs at home and abroad are made up of forest activities based on nature that these youth can adapt and challenge themselves to forest environment so as to foster positive emotion and improve abilities to solve problematic situations they face. Ultimately it can correct their delinquent nature and prevent them from recommitting crimes, so that they can return to the society in a sound way.

Accordingly this study was made up of detailed activities such as physical activities, meditation, ecological activities, self-exploratory activities, artistic activities where they can get to know themselves with waking up their physical senses, experience various elements of a forest to solve various problems in a forest, explore their own dreams with self-reflection and make the best use of natural objects for artistic activities. In addition, these programs were hosted by forest education professionals in a collective or individual activity. Moreover, probation officers observed on site to make sure their active participation (Table 1).

Table 1. Activity contents of forest education.

\begin{tabular}{|c|c|c|c|}
\hline \multicolumn{2}{|c|}{ Division } & Activity contents & Goals \\
\hline \multicolumn{2}{|l|}{ Physical activity } & $\begin{array}{l}\text { - Physical exercises in the forest } \\
\text { - Awakening up five senses }\end{array}$ & $\begin{array}{l}\text { - Getting to know each other by dynamic group physical } \\
\text { activity in forest }\end{array}$ \\
\hline \multicolumn{2}{|l|}{ Cognitive activity } & - Observing forest with mirror & $\begin{array}{l}\text { - Knowing the value of forest by experiencing various } \\
\text { components in the forest }\end{array}$ \\
\hline & $\begin{array}{l}\text { Artistic } \\
\text { activity }\end{array}$ & - Creating with natural objects & - Enhancing creativity and feeling a sense of achievement \\
\hline
\end{tabular}




\section{Measurement Tools}

In consideration of the previous researches on the effects of specific activities or programs targeting juvenile probationers, the studies were mostly focus on verifying positive effects on behavior correction such as individual and social problem solving, emotional area such as self-esteem, self efficacy or self-recognition, relational area such as social support, interpersonal relation change, change in attitude toward school life and educational area such as career preparation or decision, horticulture knowledge, attitude towards environment (Table 2).

This study selected resilience scale about coping with and solving various problem situations occurring in their own environments, mood state scale about measuring emotional changes in forest and scale of attitude toward forest to see changes in their recognition about importance of interest and protection toward forest through forest education on juvenile probationers.

\section{1) Resilience}

Resilience can be defined as a power of effective handling of problems or stressful situations and making adaptation even with risks (Garmezy, 1991; Ryff and Singer, 2007). Since those with lower resilience can be easily discouraged and become impulsive and fail to efficiently handle stressful situation (An and Park, 2016a), it is all the more important for juvenile probationers to grow the ability of handling personal or external emergency situations. Therefore this study figured out the changes in their resilience after conducting forest education program on these juvenile probationers and as for resilience scale we adopted resilience scale of Grothberg (1997) in his 'the International Resilience project' and Joo and Lee (2011) adopted the resilience scale of Oshio et al. (2003), which were recomposed to 'resilience scale for youth' in order to apply to young people. A total of 23 questions were used with a scale of five points.

Table 2. Preferences of program for juvenile probationers.

\begin{tabular}{|c|c|c|}
\hline Research contents and method & Used scale & Author \\
\hline $\begin{array}{l}\text { The relation between social problem solving ability and } \\
\text { social supports } \\
\text { Experiment }(N)=221\end{array}$ & $\begin{array}{l}\text { Social problem solving inventory (SPSI) } \\
\text { Social support scale }\end{array}$ & $\operatorname{Kim}(1998)$ \\
\hline $\begin{array}{l}\text { The effectiveness of the mentoring program } \\
\text { Experiment }(N)=15 \text {, Control }(N)=10\end{array}$ & $\begin{array}{l}\text { Juvenile delinquency scales } \\
\text { Inventory of social supportive behaviors (ISSB) } \\
\text { Personal factors (Self-control, Self-efficacy) }\end{array}$ & $\mathrm{Ha}(2001)$ \\
\hline $\begin{array}{l}\text { The effects of social competence promotion program } \\
\text { Experiment }(N)=18 \text {, Control }(N)=18\end{array}$ & $\begin{array}{l}\text { Self-efficacy scale } \\
\text { Social problem solving inventory } \\
\text { Relationship Change Scale }\end{array}$ & Cheong (2005) \\
\hline $\begin{array}{l}\text { The comparison of the career self-efficacy, career decision } \\
\text { level and career preparation behavior } \\
\text { Experiment }(N)=114 \text {, Control }(N)=147\end{array}$ & $\begin{array}{l}\text { Career decision-making self-efficacy short form (CDMSE-SF) } \\
\text { Career decision scale } \\
\text { Career exploration survey } \\
\text { Vocational questionnaire } \\
\text { Career planning questionnaire }\end{array}$ & Moon (2010) \\
\hline $\begin{array}{l}\text { Tea culture therapy program development for social } \\
\text { adaptability improvement } \\
\text { Experiment }(N)=20\end{array}$ & $\begin{array}{l}\text { Self-efficacy scale } \\
\text { Self-control scale } \\
\text { relationship change scale }\end{array}$ & $\operatorname{Kim}(2014)$ \\
\hline $\begin{array}{l}\text { Group art therapy case study } \\
\text { Experiment }(N)=4\end{array}$ & $\begin{array}{c}\text { Self-efficacy scale } \\
\text { Problem behavior (Korea-Youth Self Report; K-YSR) }\end{array}$ & Lee (2017) \\
\hline $\begin{array}{l}\text { Identification of depression } \\
\text { Experiment }(N)=32\end{array}$ & $\begin{array}{l}\text { Children's Depression Inventory } \\
\text { (Control Scale, Self-Concept Scale) }\end{array}$ & Cole et al. (1981) \\
\hline $\begin{array}{l}\text { The effects of community based horticultural program } \\
\text { Experiment }(\mathrm{N})=50\end{array}$ & $\begin{array}{l}\text { Horticultural knowledge } \\
\text { Environmental attitudes }\end{array}$ & $\begin{array}{l}\text { Cammack et al. } \\
\text { (2002) }\end{array}$ \\
\hline $\begin{array}{l}\text { The effects of horticultural program } \\
\text { Experiment }(N)=50\end{array}$ & $\begin{array}{l}\text { Self-esteem } \\
\text { Interpersonal relationships } \\
\text { Locus of control } \\
\text { Attitude toward school }\end{array}$ & $\begin{array}{l}\text { Cammack et al. } \\
\text { (2002) }\end{array}$ \\
\hline
\end{tabular}




\section{2) Mood state}

We used 'mood state' scale to measure immediate emotional response from forest activities of these juvenile probationers. We adopted mood state scale, developed by Campbell et al. (1976), 'Index of Well-being' which was translated by Lee (1998) to recompose into eight questions that question 'feeling for life', sub-factor from 'criteria of subjective quality of life'. 'Feeling for life' is to ask participants their emotional state concerning recent experience, which was named 'mood state' in this study. This is semantic differential scale that each question suggests a pair of adjectives related to oppositive moods located in both ends and the scale of points ranges from one to seven so that the respondents can check the appropriate mood. When the lower the point is, the more positive you feel, the higher the point is the more negative mood you have.

\section{3) Attitude towards Forest}

We used the scale of the 'attitude toward forest' in order to measure changes of juvenile probationers in their awareness, perspective and expectations toward forest before and after forest education programs. This was based on the scale developed by Wendling and Wuensch (1985; Joo, 2001 re-cited) but modified and complemented by Joo (2001). In detail items, there are 13 questions that ask 'interest in forest', 'forest protection and importance'. Each question has a scale of five points and when average value from the questions in pre-post questionnaires are analyzed and the differences are checked statistically, the changes in the attitude towards forest are objectively recognized.

\section{Method of data collection and analysis}

This study performed a self-filling questionnaire before and after program participation in order to assess the effects of forest education program targeting juvenile probationers. We collected 430 copies of pre-questionnaires and 391 copies for post-questionnaires. However, we excluded cases that are mismatched with pre- and post- questionnaires and unfaithful responses so that a total of 272 copies of pre- and postquestionnaires were used ultimately. For analysis of this collected data, we used SPSS 21.0 program and conduct technical statistics analysis, reliability analysis, and corresponding sample t-verification.
We performed exploratory factor analysis for verifying validity of measuring tools and used the same pre-questionnaire data with the same scale that is used repeatedly before and after the program. Principle component analysis was also performed to extract factors for scales of mood state, attitude toward forest and resilience and Varimax method was selected. Through Bartlett's sphericity test, we checked whether Chi-Square $\left(\chi^{2}\right)$ is lower than 0.05 of significance level and whether KMO value is higher than 0.5 through KMO (Kaiser-Meyer-Olkin) test and then conduct reliability analysis to check internal consistency of questions (Hair et al., 1998).

\section{Results and Discussions}

\section{General Characteristics of Participants}

General characteristics of participants are as follows (Table 3). The gender of 272 juvenile probationers participating in

Table 3. Demographics of participants.

\begin{tabular}{|c|c|c|c|}
\hline \multicolumn{2}{|r|}{ Variables } & $\begin{array}{c}\text { Frequency } \\
\text { (N) }\end{array}$ & $\begin{array}{c}\text { Percentage } \\
(\%)\end{array}$ \\
\hline \multirow{2}{*}{ Gender } & Male & 253 & 93.0 \\
\hline & Female & 19 & 7.0 \\
\hline \multirow{7}{*}{ Age } & 15 & 7 & 2.6 \\
\hline & 16 & 31 & 11.4 \\
\hline & 17 & 58 & 21.3 \\
\hline & 18 & 73 & 26.8 \\
\hline & 19 & 71 & 26.1 \\
\hline & 20 & 29 & 10.7 \\
\hline & 21 & 3 & 1.1 \\
\hline \multirow{6}{*}{ Concern } & Academic & 53 & 19.5 \\
\hline & Career & 126 & 46.3 \\
\hline & Interpersonal relationship & 7 & 2.6 \\
\hline & Family situation & 3 & 1.1 \\
\hline & Economic condition & 26 & 9.6 \\
\hline & Others & 57 & 21.0 \\
\hline \multirow{7}{*}{$\begin{array}{l}\text { Academic } \\
\text { background }\end{array}$} & In middle school & 39 & 14.3 \\
\hline & Dropout of middle school & 17 & 6.3 \\
\hline & Graduated middle school & 10 & 3.7 \\
\hline & In high school & 104 & 38.2 \\
\hline & Dropout of high school & 76 & 27.9 \\
\hline & Graduated high school & 26 & 9.6 \\
\hline & Total & 272 & 100.0 \\
\hline
\end{tabular}


forest education program is mostly male $(93.0 \%)$. The age is from 15 to 21 with 18 (26.8\%)', '19 (26.1\%)' and '17 (21.3\%)' as majority age groups. As a result of the research on their current concerns, "career" comes first with $46.3 \%$, 'others $(21.0 \%)$ ' and 'education (19.5\%)' in order. Others include a combination of concerns on career, education, etc. As for educational background, enrolled students in high school (38.2\%), dropout from high school (27.9\%) and enrolled in middle school (14.3\%) are in order. The number of juvenile probationers that are enrolled in middle or high school is 143
(52.5\%) and those who are not enrolled in schools are 129 $(47.5 \%)$ due to dropout or failure to promote to the higher education, etc.

\section{Verification of Effects of Forest Education Program}

\section{1) Resilience}

As for resilience questions, a total of 22 questions were used for final analysis after removing questions with .40 of commonality. As a result of major component analysis, we confirmed

Table 4. Exploratory factor analysis: Resilience.

\begin{tabular}{|c|c|c|c|c|}
\hline & \multirow{2}{*}{ Items } & \multicolumn{3}{|c|}{ Factors } \\
\hline & & 1 & 2 & 3 \\
\hline \multirow{9}{*}{ Self-efficacy } & I can do my best to accomplish the given tasks & .783 & .393 & .236 \\
\hline & I love and trust myself & .772 & .314 & .327 \\
\hline & I have enough energy to do what I have to do & .764 & .414 & .239 \\
\hline & I can lean on my family whenever I need them & .736 & .215 & .411 \\
\hline & I think I can deal with whatever comes & .703 & .442 & .323 \\
\hline & My life has meaning & .693 & .333 & .391 \\
\hline & I am active and cheerful & 642 & .535 & .201 \\
\hline & I have a person who I love much & .575 & .569 & .153 \\
\hline & When difficult problems come in my way, I get lessons coping with them & .570 & .502 & .337 \\
\hline \multirow{8}{*}{$\begin{array}{l}\text { Trust in self } \\
\text { and others }\end{array}$} & I can easily make friends & .292 & .753 & .324 \\
\hline & I can make tough decisions that others can't & .385 & .727 & .323 \\
\hline & I'm not afraid to try new things & .387 & .702 & .370 \\
\hline & I can accept other's opinion even though it is different from mine & .429 & 632 & .424 \\
\hline & I can keep smiling when I go through a hard time & .357 & .626 & .407 \\
\hline & I am proud of my achievements & .551 & .624 & .275 \\
\hline & I can talk to others about things that bother me & .526 & .568 & .378 \\
\hline & I practice on my own to achieve something & .472 & .532 & .437 \\
\hline \multirow{5}{*}{$\begin{array}{l}\text { Tolerance of } \\
\text { negative } \\
\text { affect }\end{array}$} & I am not easily annoyed when things don't go my way & .210 & .229 & .863 \\
\hline & I can control my negative emotions such as anger, sadness & .311 & .282 & .793 \\
\hline & Even though something upsets my mind, I can deal with other things assigned to me & .289 & .392 & .762 \\
\hline & I can figure out when it is a good time to talk to someone or to take action & .489 & .447 & .610 \\
\hline & I know how to calm down upset mind & .509 & .446 & .517 \\
\hline & Eigenvalue & 6.596 & 5.697 & 4.519 \\
\hline & Explained variance $(\%)$ & 29.982 & 25.896 & 20.543 \\
\hline & Overall accumulated variance $(\%)$ & & 76.421 & \\
\hline \multicolumn{5}{|c|}{$\begin{array}{c}\text { Extraction method : Principal component analysis, } \mathrm{KMO}=.970, \chi^{2}=13080.741(\mathrm{df}=231, p=.000) \\
\text { Extraction method: Varimax }\end{array}$} \\
\hline \multirow{2}{*}{\multicolumn{2}{|c|}{ Cronbach's $\alpha$}} & .956 & .950 & .926 \\
\hline & & & .977 & \\
\hline
\end{tabular}


they are appropriate for factor analysis with the result of $\chi^{2}$ $=13080.741(\mathrm{df}=231, p=.000), \mathrm{KMO}=.970$ (Table 4). It turned out that the sub-factors of resilience is three in total. Factor one questions have something to do with self-efficacy such as 'I can do my best to accomplish the given tasks', 'I love and trust myself', 'I have enough energy to do what I have to do', etc so that it was named 'self-efficacy'. Factor two questions are about trust in self and others such as 'I can make friends easily', 'I can make tough decisions that others can 't.' and 'I can accept others' opinion even though they are different from mine', etc so that it was named 'trust in self and others'. Also, the factor three includes questions such as 'I am not easily annoyed when things do not go my way', 'I can control my negative emotions such as anger and sadness' and 'even though somethings upsets my mind, I can deal with other things assigned to me' so that it was named 'tolerance of negative emotion'. As a result of Cronbach's $\alpha$ analysis, the scale of the questionnaire is 'self-efficacy' .956, 'trust in self and others' .950 , 'tolerance of negative emotion' .926, and 'overall resilience' .977, which shows internal consistence.

The resilience of the juvenile probationers rose from 3.466 before program participation to 3.749 after, which is statistically significant increase $(t=-6.541, p=.000)$. In case of sub-factors of resilience, the average score of 'self-efficacy' increased from 3.541 in pre-program to 3.823 in post-program ( $t=-6.131$, $p=.000$ ), 'trust in self and others' went up from 3.436 to 3.735 $(t=-6.498, p=.000)$, and 'tolerance of negative emotion' rose from 3.378 to 3.641 ( $t=-5.302, p=.000)$, sub-factors show they are statistically significant (Table 5).
This shows that after forest education program participation, these juvenile probationers got better in their resilience, an ability to restore their capacity and to positively adapt themselves even with exposure of problem situations than before. As in the study results of Mun and Yang (2012), when we consider problematic behaviors of the youth and their countermeasures, this study shows that forest education program can be an educational alternative that can restore self-efficacy, social adaptiveness and problem-solving ability of juvenile probationers who have social problems.

\section{2) Mood State}

As a result of analyzing major component against eight mood state questions, $\chi^{2}=6414.304(\mathrm{df}=28, p=.000), \mathrm{KMO}=.957$ turned out to be appropriate for factor analysis. As a result of analysing factor reliability, the overall reliability (Cronbach's $\alpha$ ) is .976, which shows internal consistence (Table 6).

As shown in Table 7, before and after participating in the forest education program, the mood state average value was 4.077 and went up to 4.988 after participating, which are statistically meaningful rise $(t=-11.081, p=.000)$. In other words, the mood of the juvenile probationers changed positively before and after participating in the forest education program. This suggests that positive emotions such as 'miserable', 'disappointing', and 'pessimistic' turned to positive emotions such as 'enjoyable', 'rewarding' and 'hopeful'. These results are similar to those of Eom et al. (2016), which suggests that positive emotions have increased so that it improves the emotions of participants thanks to the experience of participating

Table 5. Result of paired t-test: Total and sub factors of Resilience.

\begin{tabular}{|c|c|c|c|c|c|}
\hline \multicolumn{2}{|c|}{ Variable } & \multirow{2}{*}{$\frac{\mathrm{M}}{3.466}$} & \multirow{2}{*}{$\begin{array}{l}\text { SD } \\
.716\end{array}$} & \multirow{3}{*}{$\begin{array}{c}t \\
-6.541\end{array}$} & \multirow{3}{*}{$\frac{p}{.000 * * *}$} \\
\hline \multirow{2}{*}{$\begin{array}{l}\text { (Total) } \\
\text { Resilience }\end{array}$} & Pre-test & & & & \\
\hline & Post-test & 3.749 & .787 & & \\
\hline \multirow{2}{*}{$\begin{array}{l}\text { (Factor } 1) \\
\text { Self-efficacy }\end{array}$} & Pre-test & 3.541 & .750 & \multirow{2}{*}{-6.131} & \multirow{2}{*}{$.000 * * *$} \\
\hline & Post-test & 3.823 & .808 & & \\
\hline \multirow{2}{*}{$\begin{array}{l}\text { (Factor2) } \\
\text { Trust in self and others }\end{array}$} & Pre-test & 3.436 & .746 & \multirow{2}{*}{-6.498} & \multirow{2}{*}{$.000 * * *$} \\
\hline & Post-test & 3.735 & .819 & & \\
\hline \multirow{2}{*}{$\begin{array}{l}\text { (Factor3) } \\
\text { Tolerance of negative affect }\end{array}$} & Pre-test & 3.378 & .806 & \multirow{2}{*}{-5.302} & \multirow{2}{*}{$.000 * * *$} \\
\hline & Post-test & 3.641 & .863 & & \\
\hline
\end{tabular}

$\mathrm{M}=$ Mean; $\mathrm{SD}=$ Standard deviation.

$* * * p<.001$ by paired t-test. 
Table 6. Exploratory factor analysis: Mood state.

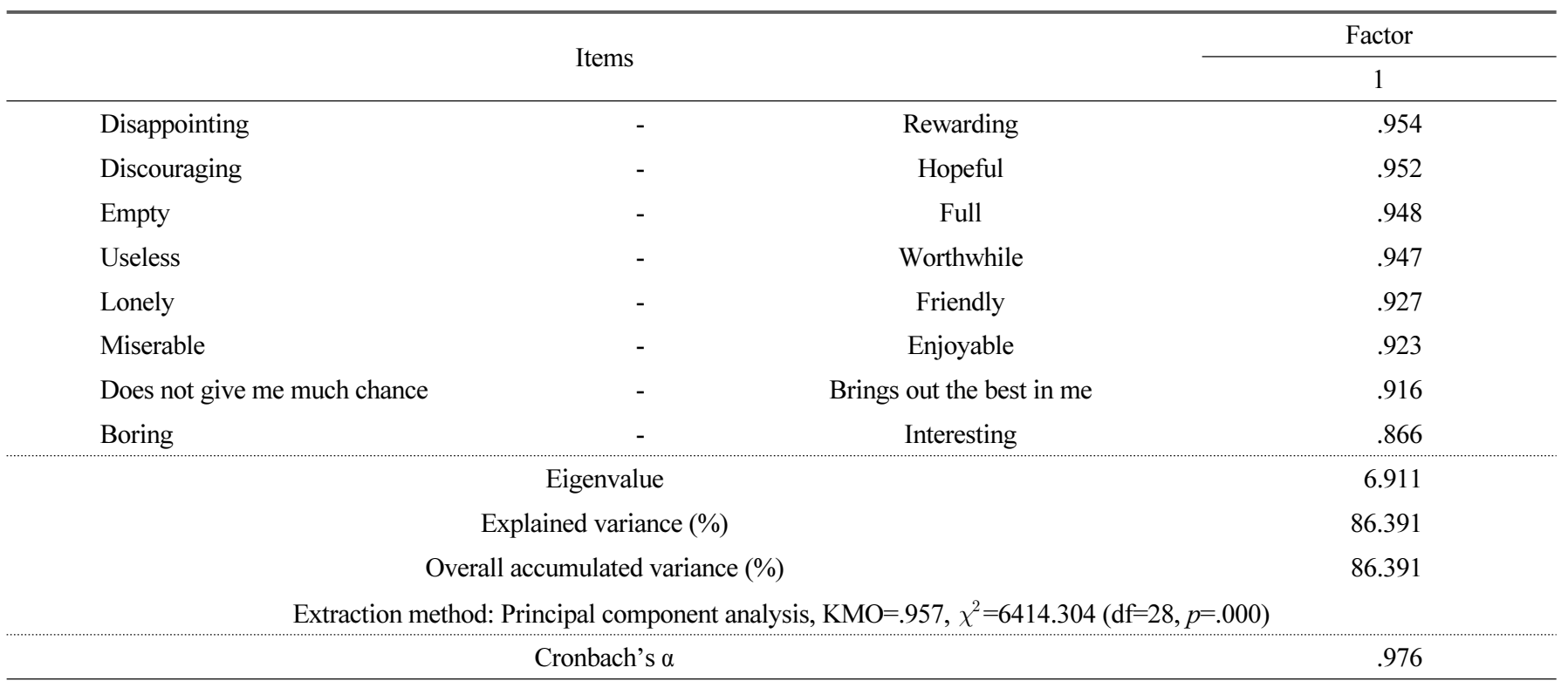

Table 7. Result of paired t-test: Mood state.

\begin{tabular}{cccccc}
\hline \multicolumn{2}{c}{ Variable } & $\mathrm{M}$ & $\mathrm{SD}$ & $t$ & $p$ \\
\hline \multirow{2}{*}{ Mood state } & Pre-test & 4.077 & 1.076 & & \\
& Post-test & 4.988 & 1.449 & -11.081 & $.000^{* * *}$ \\
& Po & & \\
\hline
\end{tabular}

$\mathrm{M}=$ Mean; $\mathrm{SD}=$ Standard deviation.

$* * * p<.001$ by paired t-test.

in forest education programs.

The results of this study were as follows: the juvenile probationers who predicted that the program would be about education for everyday school life and delinquent behavior before participating in the program had come to feel freshness and pleasure from diverse experiences in forests, which would have affected the change to positive emotion.

\section{3) Attitude towards Forest}

In final analysis, a total of 12 questions were used for attitude towards the forests after removal of items with a commonality of less than .40. The result of the principal component analysis is $\chi^{2}=575.606(\mathrm{df}=45, p=.000), \mathrm{KMO}=.834$. which confirms its appropriateness for factor analysis. As for the characteristics of each factor, there are two sub-factors. Factor one is an interest in forests such as 'I am very much interested in forests', 'the forest is an interesting place to learn about nature', 'I prefer to learn in forest than in school when I learn about nature' so that this was named 'enjoying the forest'. Factor 2 is items about their recognition of forest as a space for protection, including 'we must protect the forests', 'humans are severely destroying the forests', 'we can not live without forests' so that it was named 'importance and usefulness of forest'. This is the same as in the study by Son et al. (2013). Cronbach's $\alpha$ of attitude toward forests showed internal consistency with 'interest in forests' 960 , 'protection and importance of forests' .908, and total .958 (Table 8).

As a result of analyzing the attitude toward the forest before and after participating in the forest education program of the probation adolescents, the average value before participating in the forest education program increased from 3.256 to 3.796 after the participation, which showed a statistically significant change ( $t=-10.539, p=.000)$. These results can be interpreted that activities such as nature observation play, forest commentary, etc., give pleasure to juvenile probationers, inducing interest in forests, and affecting them to recognize forests as an interesting space as well as a space to be protected (Table 9).

This result showed that forest commentary program can help participants to feel the wonder and curiosity of the forest and to remind participants about the importance of forests by creating new insights and interests about the forest environment, which is similar to the results of Joo (2001). 
Table 8. Exploratory factor analysis: Attitude towards forest.

\begin{tabular}{|c|c|c|c|}
\hline & \multirow{2}{*}{ Items } & \multicolumn{2}{|c|}{ Factors } \\
\hline & & 1 & 2 \\
\hline \multirow{8}{*}{ Enjoying the forest } & I'm very interested in the forest & .856 & .208 \\
\hline & The forest is an interesting place to learn about nature & .845 & .354 \\
\hline & I prefer to learn in forest than in school when I learn about nature & .841 & .317 \\
\hline & I like to go to the forest & .836 & .307 \\
\hline & The forest is a fun place & .828 & .320 \\
\hline & The forest is a good place to learn about nature & .750 & .494 \\
\hline & I feel comfortable in the forest & .736 & .492 \\
\hline & I feel grateful to the forest & .722 & .510 \\
\hline \multirow{4}{*}{$\begin{array}{l}\text { Importance and } \\
\text { usefulness of forest }\end{array}$} & We must protect forests & .347 & .851 \\
\hline & Humans are destroying forests harshly & .307 & .837 \\
\hline & We can't live without forests & .278 & .807 \\
\hline & Both the creatures living in forest and men are important lives & .351 & .798 \\
\hline & Eigenvalue & 5.579 & 3.926 \\
\hline & Explained variance (\%) & 46.489 & 32.720 \\
\hline & Overall accumulated variance $(\%)$ & \multicolumn{2}{|c|}{79.209} \\
\hline \multicolumn{4}{|c|}{$\begin{array}{c}\text { Extraction method: Principal component analysis, } \mathrm{KMO}=.834, \chi^{2}=575.606(\mathrm{df}=45, p=.000) \\
\text { Rotation method: Varimax }\end{array}$} \\
\hline \multicolumn{2}{|r|}{ Cronbach's $\alpha$} & .960 & .908 \\
\hline
\end{tabular}

Table 9. Result of paired t-test: Total and sub factors of Attitude towards forest.

\begin{tabular}{|c|c|c|c|c|c|}
\hline Variable & & M & $\mathrm{SD}$ & $t$ & $p$ \\
\hline \multirow{2}{*}{$\begin{array}{l}\text { (Total) } \\
\text { Attitudes toward forest }\end{array}$} & Pre-test & 3.256 & .805 & \multirow{2}{*}{-10.539} & \multirow{2}{*}{$.000 * * *$} \\
\hline & Post-test & 3.796 & .835 & & \\
\hline \multirow{2}{*}{$\begin{array}{l}\text { (Factor1) } \\
\text { Enjoying the forest }\end{array}$} & Pre-test & 3.070 & .900 & \multirow{2}{*}{-11.417} & \multirow{2}{*}{$.000 * * *$} \\
\hline & Post-test & 3.717 & .875 & & \\
\hline \multirow{2}{*}{$\begin{array}{l}\text { (Factor2) } \\
\text { Importance and usefulness of forest }\end{array}$} & Pre-test & 3.631 & .854 & \multirow{2}{*}{-5.927} & \multirow{2}{*}{$.000 * * *$} \\
\hline & Post-test & 3.955 & .871 & & \\
\hline
\end{tabular}

$\mathrm{M}=$ Mean; $\mathrm{SD}=$ Standard deviation.

$* * * p<.001$ by paired t-test.

In terms of the sub-factors, 'interest in forest' showed a statistically significant change $(t=-11.417, p=.000)$ since the average score went up from 3.070 to 3.717 before and after participation in the forest education program. In 'importance and usefulness of forest' factor, there was meaningful change since average value before the participation rose from 3.631 to 3.955 after participation $(t=-5.927, p=.000)$.

In other words, we observed that during the process of participating forest education program (physical activities such as meditation to awaken a sense of body or relaxation, ecological experience activities in which various components of the forest are learned, and craft activities using natural things) juvenile probationers have been positively affected in the positive attitude change in that they recognize forest positively and understand importance of forest. 


\section{Conclusion}

This study examined the effect of the forest education program on the resilience, mood state, and attitude of the forests of the probation adolescents, which has been conducted jointly by Korea Forest Service and the Ministry of Justice, and the results are as follows .

First, forest education programs have positive effect on changes in resilience of juvenile probationers, which is statistically meaningful. In terms of sub-factors, forest education activities have a positive effect on the improvement of selfefficacy, social adaptability and problem solving ability of juvenile probationers. This is because the relationship between the forest commentator, juvenile probationers, and the participants of each group is formed as a result of various activities in the forest and it also affects the attitude of juvenile probationers during resolving the mission such as forest exploration or craft-making. In addition during the process of solving difficult problems or achievement, they can develop the ability to endure negative emotions. All of these can be interpreted to be effective in restoring their resilience. This result is consistent with the study by Kim (2014) that forest activities can reduce the negative emotions of participants.

Second, as a result of comparing the mood state before and after participating in the forest education program, the forest education significantly affects the change of the mood state of the participants positively and meaningfully. This result confirms that forest education can be a positive experience to strengthen the protective factors of juvenile probationers. In other words, participation in forest education allows positive emotional factors from forest experience to become buffer for risk factors that juvenile probationers hae and help strengthen the protection factor by removing negative emotions (Kim, 2014).

Third, as a result of examining attitude towards forest before and after participating in the forest education program, it was found that forest education has a significant effect on positive attitude change towards forest. In other words, the participation of juvenile probationers promoted the interest and curiosity towards forests and enhance their recognition of the importance of forests, which supports the study of Eom et al. (2015) that the experience in forests has a positive effect on the participants' attitude towards forest.
This study has identified that as they participate in forest activities, juvenile probationers improve resilience in a meaningful way since their self-efficacy which enables them to establish confidence on their own increases and they can form trust to others and increase problem-solving ability. In addition, the forest education program proved that it can induce the interest of probation juvenile probationers and achieve emotional stability and changes in positive attitude towards forest through mood improvement.

Through this study results, we expect that the forest education will be gradually expanded and applied to help correct juvenile probationers who are exposed to diverse risk factors. To this end, it is necessary to conduct continuous monitoring of the effectiveness of forest education programs for these young people, as well as a study to improve the quality of programs in consideration of the characteristics and types of juvenile probationers.

\section{References}

An, S.M. and K.I. Park. 2016a. A study of the effect of the life respect program on the sense of life respect and ego-resilience of teenagers from low-income families. Stud. Korean Youth 27(1): 5-32. DOI: 10.14816/sky.2016.27.1.5

An, Y.S. and K.T. Park. 2016b. The Factors Affecting the Rehabilitation of Aelinquent Juvenile Protected by Facilities. J. Welf. Correct. 43:99-118.

Cammack, C., T.M. Waliczek, and J.M. Zajicek. 2002. The green brigade: the educational effects of a community-based horticultural program on the horticultural knowledge and environmental attitudes of juvenile offenders. HortTechnology 12(1):77-81.

Cammack, C., T.M. Waliczek, and J.M. Zajicek. 2002. The green brigade: the psychological effects of a community based horticultural program on the self-development characteristics of juvenile offenders. HortTechnology 12(1):82-86.

Campbell, A., P.E. Converse, and W.L. Rodgers. 1976. The quality of American life: Perceptions, evaluations, and satisfactions, Russell Sage Foundation. New York, U.S.A. p.583.

Cheong, K.H. 2005. The effects of social competence promotion program on the adolescents in a probation center. MS Thesis, Yeungnam Univ., Gyeongbuk, Korea.

Cho, Y.O. 2012. A Study on the introduction of correctional program accreditation. Korean J. Probat. 12(1):69-102.

Cole, E. and C.I. Kumchy. 1981. The CIP battery: identification of depression in a juvenile delinquent population. J. Clin. Psychol. 37(4):880-884. DOI: 10.1002/1097-4679(198110)37:4<880::AIDJCLP2270370436>3.0.CO;2-8 
Crime Prevention Policy Bureau. 2016. Probation. Retrieved from: http://www.moj.go.kr/HP/TSPB/spb_50/spb_50202010.jsp

E-Country Index. 2017. Second conviction rate of provationer. Retrieved from http://www.index.go.kr/potal/main/EachDtlPage Detail.do?idx cd=1736\#quick 02

Eom, M.S., S.Y. Ha, and Y.H. Lee. 2015. Effect of Forest Experience on Female High School Students' Attitudes toward Forest, Environmental Sensitivity, and State-Trait Anxiety. J. Korean Inst. For. Recreat. 19(4):45-52.

Eom, M.S., Y.H. Lee, and S.Y. Ha. 2016. Effect of Forest Education Program on Juvenile Probationers' Mood States, Self-esteem, and Self Control. J. Korean For. Soc. 105(2):253-260. DOI: 10.14578/ jkfs.2016.105.2.253

Garmezy, N. 1991. Resiliency and vulnerability to adverse developmental outcomes associated with poverty. Amer. Behav. Sci. 34(4):416-430. DOI: 10.1177/0002764291034004003

Grothberg, E. 1997. The international resilience project. In John, M. (Ed.) A charge against society: The child's right to protection. Jessica Kingsley Publisher, p.19-32.

Ha, S.M. 2001. The effectiveness of the mentoring program for juvenile delinquents. MS Thesis, Hallym Univ., Gangwon-do, Korea.

Hair, J.F., R.E. Anderson, R.L. Tatham, and W.C. Black. 1998. Multivariate data analysis. 5th edition, Prentice Hall, New Jersey, U.S.A. p.768.

Hong, E.A. 2000. A study on the effects for delinquent juveniles counselling under probation. MS Thesis, Yonsei Univ., Seoul, Korea.

Hwang, J.G. 2010. Study about self Control program for youth under protection surveillance. Korean J. Probat. 10(2):287-324.

Jang, E.O. 2010. Effects of marital conflict and stress on emotional/ behavioral problems with resilience as a mediator in adolescents. PhD Diss., Chosun Univ., Gwangju, Korea.

Joo, S.H. 2001. Measuring the environmental attitude effects of forest environmental interpretation program. Curr. Res. Agric. Life Sci. 19:9-16

Joo, Y.S. and M.C. Lee. 2008. A qualitative study of the daily lives of juvenile delinquents following a second offense. Stud. Korean Youth 19(1):5-31.

Ju, S.Y. and Y.H. Lee. 2011. Development and validation of the resilience scale for adolescents(RSA). Korean J. Youth Stud. 18(4):103-139.

Kim, K.H. 1998. The relation between social problem solving ability and social supports of probation adolescents. MS Thesis, Catholic Univ., Gyeonggi-do, Korea.

Kim, M.H. 2014. A study on the positive effects of forest activities for children from economically underprivileged households on their emotional state, life satisfaction, and ego-resilience. Korean J. Child Stud. 35(4):223-247. DOI: 10.5723/KJCS.2014.35.4.223

Kim, J.H. and H.R. Lee. 2006. The effects of organized camp group counseling on children's school adjustment through forest experiences. Korea J. Couns. 7(3):849-864.

Kim, J.J. 2009. A Study on Young Children's Curiosity and Nature-
Friendly Attitude Shown Through Their Nature Experiential Activities. Korean J. Child. Media 8(2):259-278.

Kim, S.B. 2012. Integrated approach of family experience on behavioral problems of adolescents. PhD Diss., Wonkwang Univ., Jeonbuk, Korea.

Kim, Y.J., J.W. Kim, K.W. Lim, Y.M. Ka, K.M. Lee, and K.J. Uh. 2015. Effects of self-efficacy and social adaptation of the probation youth dance performance experience. Korean J. Probat. 15(1):281-310.

Kim, Y.S. 2011. The Influence of Forest Therapeutic Program on the Depression and Self-esteem of Middle School Students in WEEclass. MS thesis, Chungbuk National Univ., Cheongju, Korea.

Kim, I.S. 2014. Tea culture therapy program development for social adaptabifity improvement of Juvenile probationers. PhD Diss., Pusan national Univ., Pusan, Korea.

Koh, J.W., K.H. Lee, and M.H. Lee. 2010. Criminal types of the Juvenile Offenders on PAI profile. Law Rev. 39:157-176.

Kwak, K.J., H.Y. Kim, and J. Yoon. 1991. The relationship between antisocial behavioral tendency and social information processing in adolescents. Korean J. Dev. Psychol. 4(1):145-156.

Lee, J.A. 2013. An analysis on utilization status and satisfaction of forest experience program for teenagers. MS Thesis, Seoul Women's Univ., Seoul, Korea.

Lee, M.S. 1998. The subjective quality of life of Korean workers and associated variables. PhD Diss., Yonsei Univ., Seoul, Korea. Retrieved from http://www.riss.kr/link?id=T3628503

Lee, M.E. 2008. Each Country's Probation Program and Improvement Guidelines for Korea's Probation Program. MS Thesis, Pusan National Univ., Pusan, Korea.

Lee, S.M. 2017. Group art therapy case study for juvenile delinquents at a juvenile protection facility: focusing on self-efficacy and problem behavior. MS Thesis, Konkuk Univ., Seoul, Korea.

Lee, S.J. 2007. Recidivism prediction based on risk assessment procedure for juvenile diversion at police. Korean J. Soc. Personal Psychol. 21(2):47-57.

Michael, K. and H. Ben-Zur. 2007. Risk-taking among adolescents: assocoations with social and affective factors. J. Adolesc. 30(1): 17-31. DOI: 10.1016/j.adolescence.2005.03.009

Moon, S.S. 2010. The comparison of the career self-efficacy, career decision level and career preparation behavior between the juveniles probation and average adolescents. MS Thesis, Chonbuk national Univ., Jeonju-si, Korea.

Mun, H.J. and S.E. Yang. 2012. A Study on the Experiences of Juvenile Delinquents Regarding the Implementation of Counseling Attendance Orders: A Focus on Positive Changes for Study Participants. Stud. Korean Youth 23(1):5-30.

National Institute of Forest Science. 2015. Forest education for juvenile probationers. Korea. kfri Forest Policy Issues. Bul. 50. Retrieved from http://know.nifos.go.kr/book/search/DetailView. ax?sid=2\&cid=163574

Noh, I.S. 2009. Factors predicting recidivism of violent juvenile probationers: study for developing LJP-RRAR (Larcenous Juvenile 
Probationers-Rapid Risk Assessment of Recidivism). Korean J. Psychol.: Gen. 28(2):449-470.

Oh, C.H., S.G. Park, T.S. Park, and I.J. Oh. 2012. The development and effects of the forest experience program for the internet addiction teenagers. Korean J. Couns. 13(5):2395-2415.

Oshio, A., H. Kaneko, S. Nagamine, and M. Nakaya. 2003. Construct validity of the adolescents resilience scale. Psychol. Rep. 93(3 suppl):1217-1222. DOI: 10.2466/pr0.2003.93.3f.1217

Pelkonen, M., Marttunen, M., and Aro, H. 2003. Risk for depression: a 6-year follow-up of Finnish adolescents. J. Affect. Disord. 77(1):41-51. DOI: 10.1016/S0165-0327(02)00098-8

Ryff, C.D. and B. Singer. 2007. What to do about positive and negative items in studies of psychological well-being and ill-being?. Psychother. Psychosom. 76(1):61-62. DOI: 10.1159/000096369

Shin, W.S., P.S. Yeoun, and J.H. Lee. 2007. The impact that a forest experience influences on a human mental state stability. Korean Inst. For. Recreat. 11(3):37-43.
Son, J.W., S.Y. Ha, and J.J. Kim. 2013. A Study on the relationship between attitudes toward forest and aggression in young people. J. Korean For. Soc. 102(1):74-81.

Son, S.Y. and C.H. Yang. 2009. A Study on the resocialization process of the juvenile delinquents employing qualitative methods. J. Social Res. 17(1):61-82.

Song, Y.J. and S.S. Choi. 2016. Experience of adaptation process after repeated juvenile delinquency. Korea J. Youth Couns. 24(1): 65-88.

Wang, G.M. 2006. A case study on group art therapy for juvenile delinquents on probation. MS Thesis, Dongguk Univ., Seoul, Korea.

Woo, S.A. 2009. Effects of interactive parent-children communication perceived by the youth on the peer conflict, depression and behavioral problem of youth. MS Thesis, Myongji Univ., Seoul, Korea. 